\title{
COMPARISON OF AIRFLOW IN TYPE 36 LOW-INCOME HOUSING UNIT USING CFD SIMULATION
}

\author{
Lestari $^{1^{*}, \text { Syaiful Muazir }}{ }^{1}$ \\ ${ }^{1}$ Departement of Architecture, Universitas Tanjungpura, Jln. Prof. Dr. H. Hadari Nawawi, Pontianak, \\ Kalimantan Barat, INDONESIA \\ *Corresponding author; Email: lestari@teknik.untan.ac.id
}

\begin{abstract}
Type 36 houses are built for people who have low incomes. Because of this, the buildings' ventilation relies on natural airflow. One of the variables that affect natural ventilation is airflow. Airflow can affect the quality of indoor air, influencing the comfort and health of those within. This study aims to evaluate the designs of type 36 buildings from the perspective of the airflow through the unit. It uses computational fluid dynamics simulations to compare the pattern and velocity of airflow in each building design. There are six designs of type 36 houses that have different layouts and placements of air vents. The results of the simulation and analysis show that rooms arranged in a way that allows for the placement of vents that were facing each other, even if they were in different rooms, generated continuous airflow without experiencing turbulence.
\end{abstract}

Keywords: Airflow; airflow velocity; type 36 house.

\section{INTRODUCTION}

According to the data from the Ministry of Public Works and Public Housing (PUPR) Republic of Indonesia, the number of housing units needed or backlogged in 2019 reached 7.6 million units (Setyawan, 2020). Type 36 house is the most soughtafter type of house by the community in Indonesia, as indicated by the $8.4 \%$ annual price increase of houses of that type compared to other types (Simorangkir, 2018). Construction of the type 36 house is carried out to fulfill the need for livable houses for people with low income. This type of house becomes sought after due to its lower price compared to others. House price is a primary factor in home preference as the majority of consumers want a relatively cheap price (Marpaung, 2011). Furthermore, a type 36 house can provide satisfaction to the consumers, especially if the building quality is taken into account (Suryanto HS, 2010).

The floor area of a type 36 house is $36 \mathrm{~m} 2$. The determination of the floor area is based on the requirement of $9 \mathrm{~m} 2$ per person for four occupants (Menteri Permukiman dan Prasarana Wilayah Republik Indonesia, 2002), referring to the need for $24 \mathrm{~m} 3$ of fresh air per adult (Sabaruddin et al., 2011). The need for fresh air must be met to provide a comfortable and healthy condition for the occupants. However, healthy and comfortable air quality is not achieved only through room volume; it also requires functioning ventilation in the building. The size of ventilation openings required to achieve a healthy and comfortable room is, at minimum, 5\%-10\% (Menteri Kesehatan Republik Indonesia, 2011) of the existing floor area.
Type 36 houses are built and designated for people who have low incomes. Therefore, the building's airflow relies on natural ventilation. The natural ventilation that occurs is determined by the type of window (Widiastuti et al., 2020; M. Liu et al., 2017), the size of the opening (Mediastika, 2002; Sacht \& Lukiantchuki, 2017), and the condition of the window opening (Heiselberg et al., 2002). The ventilation level is determined by measuring the amount of air change that occurs within one hour inside a room, also known as Air Changes Per Hour (ACH). Health risks may occur if the ventilation level is lower than 0.4 ACH (Wargocki, 2013). However, aside from ventilation level, air quality is also affected by the transmission of infectious particles, the potential for which is also determined by the route of movement from the source (Memarzadeh and Xu, 2012) and the size of the infectious particle (Faulkner et al., 2015). The ventilation level is not always significant in decreasing the mass concentration of infectious particles (Yang et al., 2019).

Airflow becomes one of the main variables affecting ventilation and the quality of indoor air. Certain airflow characteristics may occur due to the effect of the position of an opening (Hawendi \& Gao, 2016) and the type of opening (Heiselberg et al., 2001). These characteristics can be observed from airflow velocity and pattern. The quality of indoor air affected by pollutant concentration is determined by the entrance of the pollutant source and the path of indoor ventilation. The same velocity of incoming air can generate various airflow characteristics and transmit pollutants in different ventilation paths (X. Liu et al., 2020). 
Indoor airflow affects not only the health of occupants but also their comfort as well. Air movement can affect the thermal comfort level of occupants (Gong et al., 2006; Tanabe and Kimura, 1989), and it depends on environmental conditions. People in tropical areas tend to favor a local airflow velocity of between 0.3 to $0.45 \mathrm{~m} / \mathrm{s}$ in a room with a temperature of $23^{\circ} \mathrm{C}$, while in the environmental temperature of $25^{\circ} \mathrm{C}$, they tend to prefer a local airflow velocity of between 0.3 to $0.9 \mathrm{~m} / \mathrm{s}$ (Gong et al., 2006). The velocity and intensity of airflow turbulence can also affect indoor comfort (Both et al., 2016). Uniform airflow patterns and velocity are needed to achieve an even comfort condition in a room (Fulpagare \& Agrawal, 2013).

A type 36 house is built in various designs to accommodate the activities of its occupants. In general, type 36 houses are designed with two bedrooms, one living room which doubles as a family room, and one bathroom. There is not much variation in the layout of type 36 houses due to their limited building area of $36 \mathrm{~m} 2$. The designation of type 36 house as a house for low-income people also causes it to be built on limited land. The left and right sides of the building are generally very close to the adjacent buildings; thus, it is usually designed with little to no openings. Window and air vent openings are maximized at the front and back of the building. Even though the footprint layouts used in the designs of type 36 houses are not very variable, different internal designs are still offered to achieve occupant comfort. The internal layouts can cause different effects on the airflow through the building. This paper aims to evaluate the effect of various layout designs of type 36 buildings on the airflow patterns which occur inside these buildings. The evaluation conducted can provide an illustrative and informative guide for increasing the air quality in type 36 building designs.

\section{METHODOLOGY}

This study used computational fluid dynamics simulations to see the airflow pattern occurring in various layout designs of type 36 buildings. Different layouts were collected through a study on secondary data; then, six designs were chosen to be evaluated. Each design was evaluated under two conditions: open bedroom door and closed bedroom door. The six house designs that were tested can be seen in Table 1 . Several sizes of type 36 houses were arranged to have the same values so that the effect of the layouts on air movement could be seen. The height and width of air vents were arranged in such a way so that the total size of air vent openings in the building was 5\% of the total floor area. This value was based on the fact that type 36 buildings are constructed on narrow and intersecting land, which limits the possibility for them to be designed with wide air vent openings. Window openings were in the front and back of the building, but they were assumed to be closed, so that airflow could only occur through the air vents. The air vents were located above the door and window at the front and back of the building. Bedrooms also had air vents that connected the air in the rooms with the family room. The front air vent was used as the inlet, while the back air vents were used as the outlets since type 36 buildings are constructed with many units arranged in a back-to-back position, so it was assumed that airflow would come from the front of the buildings. It was also assumed that the airflow that occurred would have a very low velocity, as in a dense housing arrangement, airflow can have a very low velocity. It could even be stagnant. This simulation used a $0.1 \mathrm{~m} / \mathrm{s}$ velocity so that evaluation of airflow with very low velocity in the layouts of type 36 buildings could be conducted.

The height of the ceiling was set at $2.8 \mathrm{~m}$ by taking into account the need for $24 \mathrm{~m} 3$ of fresh air per adult. Air movement was evaluated from two positions: standing and sitting. Both of the positions are at standard heights for the occupants' activities; therefore, they are used as evaluating positions for the airflow. The standing position was set at the height of $1.4 \mathrm{~m}$, while the sitting position was set at the height of $0.65 \mathrm{~m}$, referring to the data of Indonesian anthropometry (Perhimpunan Ergonomi Indonesia, 2013).

\section{RESULTS AND DISCUSSION}

Simulations were conducted on six house designs, and each design was evaluated with two conditions: open bedroom door and closed bedroom door. Both of these conditions were used to see the effect of an obstacle on the airflow patterns which occurred in the room. Indoor obstacles such as walls have a strong effect on airflow patterns (Posner et al., 2003). Table 2 shows the simulation results of the six house designs.

The airflow which occurred in each design showed that there were patterns which formed turbulent vortices, as displayed in Table 2. Airflow occurring in a room can be subject to turbulence due to the existence of a divider that restricts air movement in the room (Hu et al., 1996). Airflow patterns can affect the comfort and quality of indoor air. Turbulence can put airflow in a cool to a neutral state, in addition to reducing the likelihood of the airflow 
Tabel 1. The Shape of Each Layout Design Evaluated

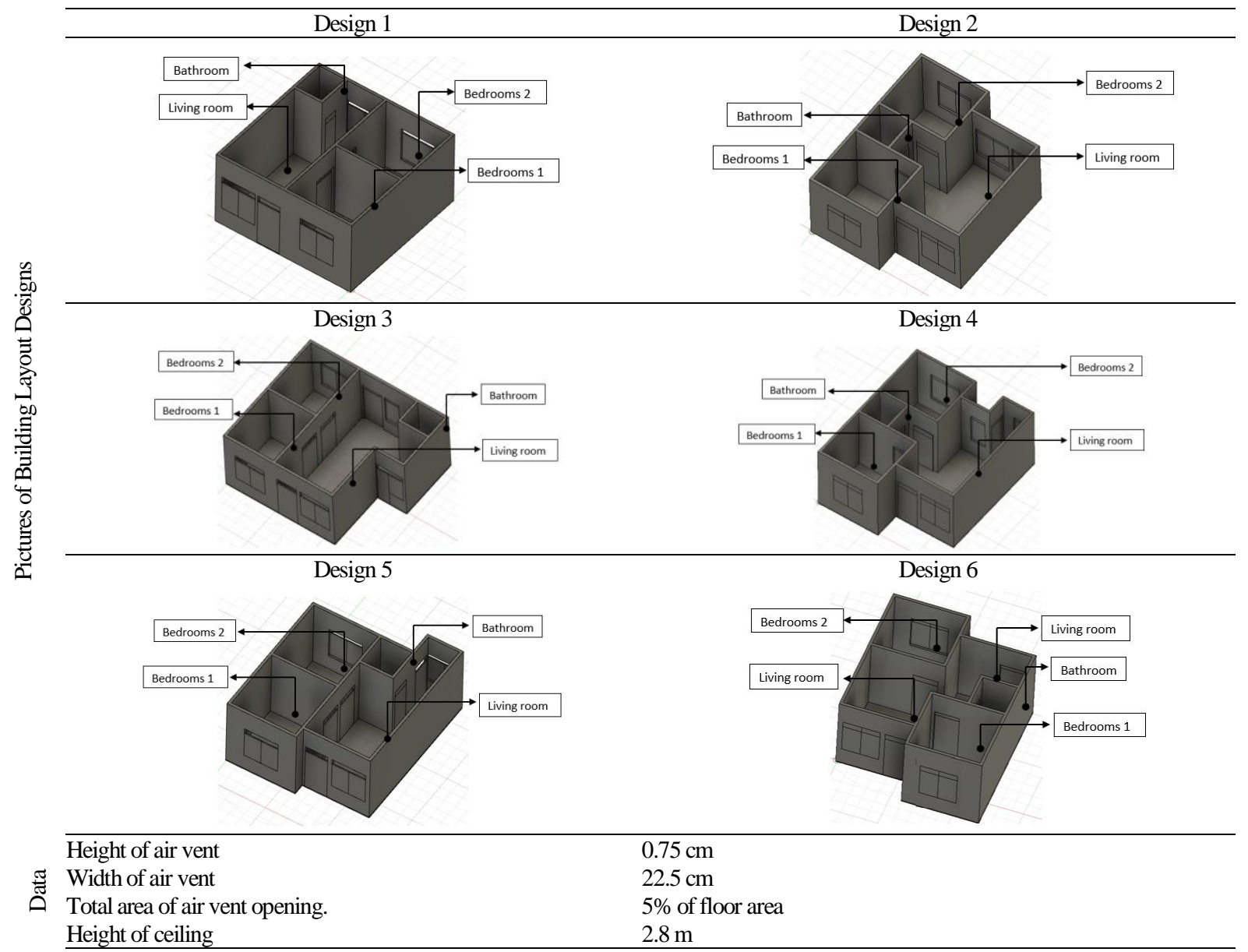
(Source: Author, 2020)

being in a neutral to warm state (Xia et al., 2000). However, in other phenomena that have been studied, the pattern may enable the air to absorb more heat and generate local warming (Prakash and Ravikumar, 2015). Aside from affecting thermal comfort, recirculating airflow can affect the pollutant content in a room. It can affect the duration of the presence of a pollutant in the air within a room, which will determine how quickly the pollutant can be eliminated. The shorter the duration of pollutants staying in a room, the fewer occupants are exposed to such substances. Therefore, the faster the airflow reaches the outlet, the more effective the ventilation becomes (Chung and Hsu, 2001).

The airflow pattern in designs No. 2, 4, and 6 showed that there was continuous movement from the front air vent toward the back vent at the height of the air vents, even if they were located in different rooms. The position of air vents that faced each other helped the air to move continuously without forming vortices. Vents on walls that face each other at the same height generate a straightforward airflow pattern which makes an efficient ventilation setup to reduce occupants' exposure to pollutants (Chung and Hsu, 2001).
Room dividers and the position of air vents had an effect on air movement and the flow patterns which were formed. This can be seen from the comparison of flow patterns in the conditions of open-door and closed-door setups. It was seen that the air moved more easily toward the outlet in the open-door condition, even if in design No. 5 it was not significant. This case showed that the room divider affected air movement. Even if a decrease in the size of openings can increase pollutant concentration in the available ventilation path (X. Liu et al., 2020), having the same size of openings that are not facing each other, as in layout No. 5, causes the turbulent vortices to become more obvious. This shows that the placement of the air vent in a sideways position does not really help the movement of airflow to the outside. The addition of an air vent in a narrow area that is not directly facing to face with the outlet wall, as in design No. 3, also does not really have an effect on the air moving toward the outside. Room dividers and the position of air vents must be designed in a way that allows air to move freely to the outside. Airflow blockage must be avoided to attain better performance in eliminating pollutants (X. Liu et al., 2018). 
Tabel 2. Airflow Conditions in six Type 36 House Designs

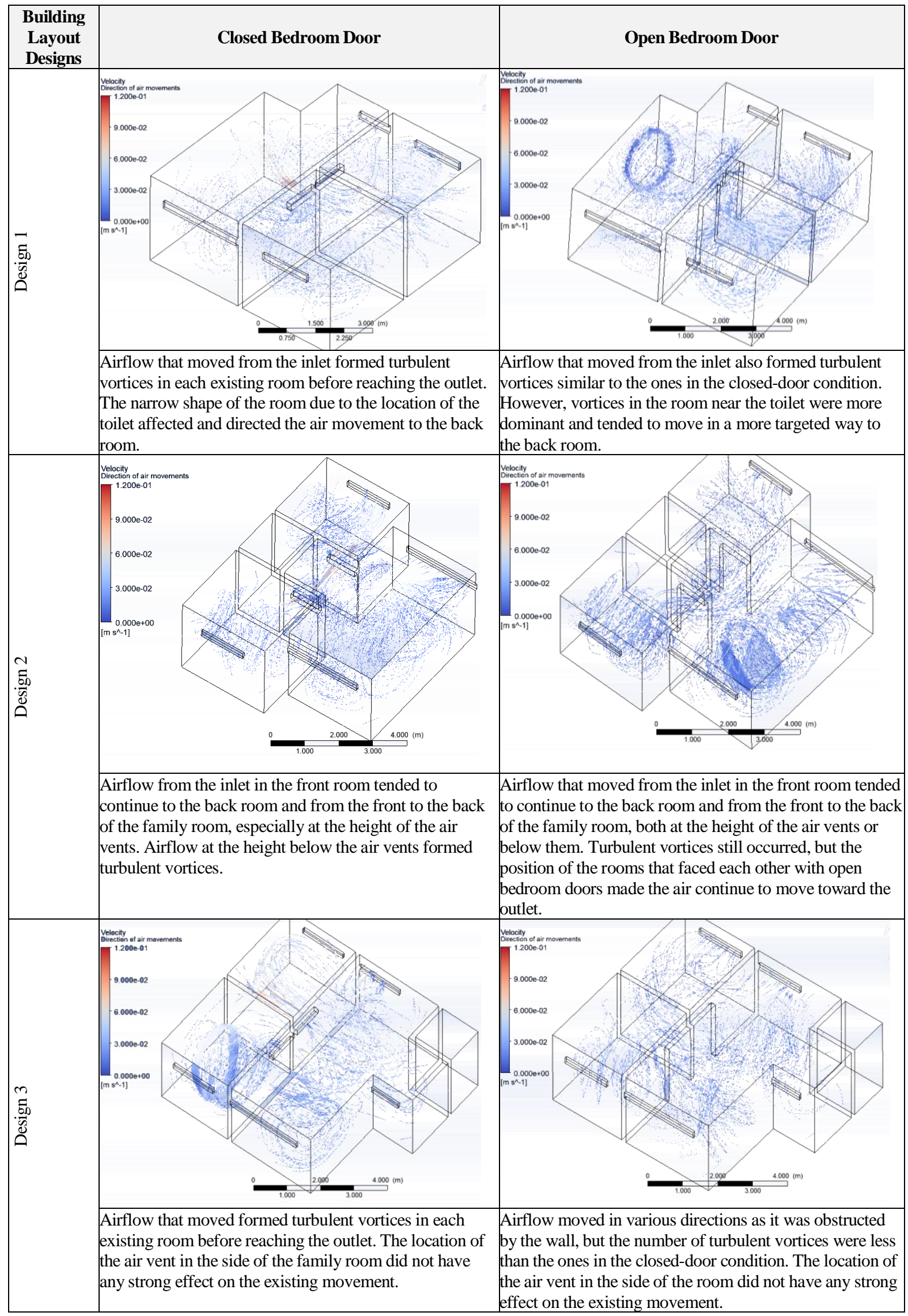




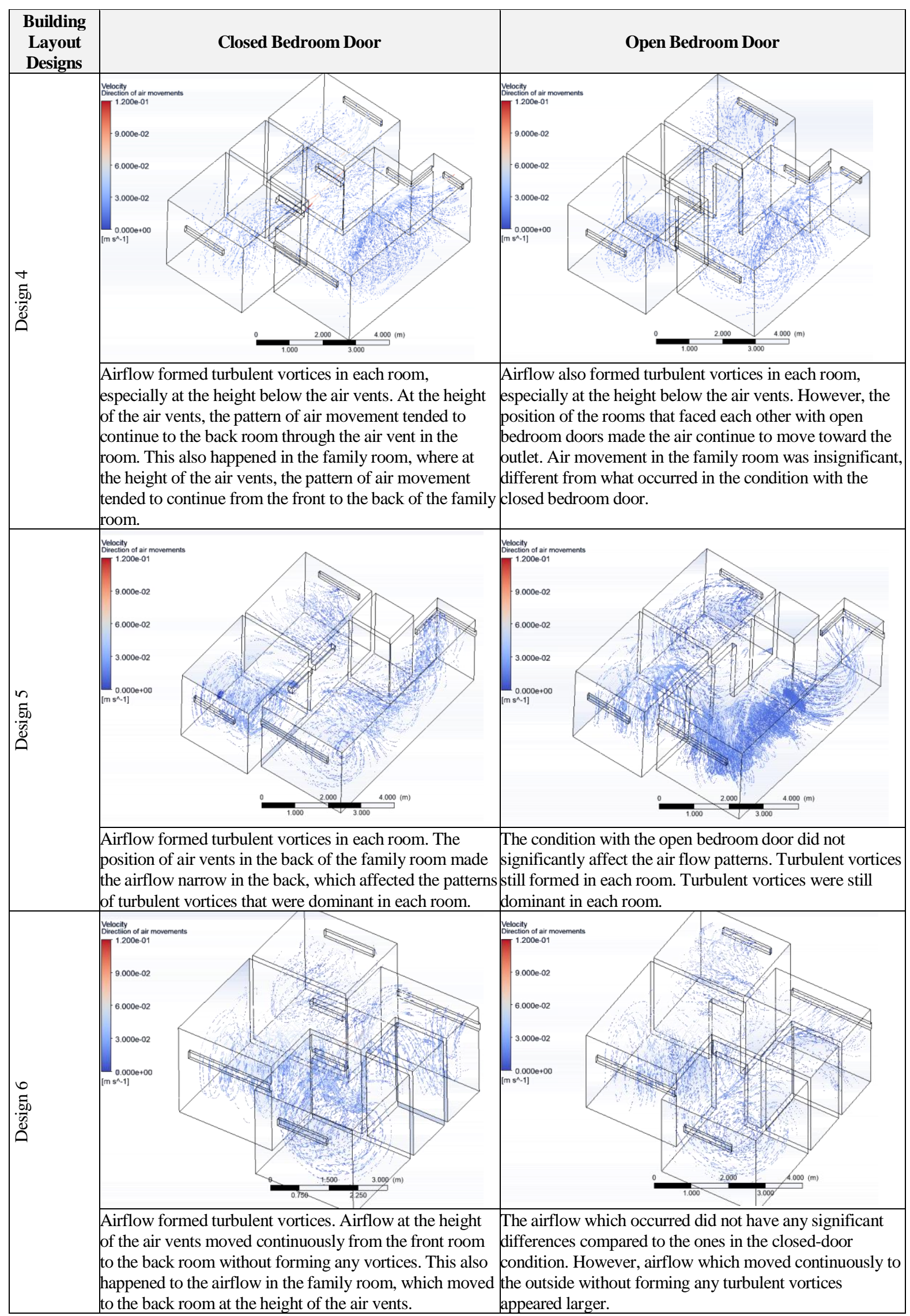

(Source: Author, 2020) 
Aside from airflow, flow velocity also has an important role in the process of achieving comfort and eliminating pollutants. Table 3 shows the airflows cut horizontally and seen from 2 heights, from sitting and standing positions. Airflows in the open door condition in all designs except No. 5 showed that some of the air moved continuously to the outside without forming turbulent vortices. However, flow velocity, which occurred in the open-door condition, tended to be slower compared to airflow velocity in the closeddoor condition. This condition becomes less favorable if the airflow velocity is very low during a state of high air temperature, where occupants tend to feel more comfortable in a higher flow velocity (Gong et al., 2006).

Table 3. Velocity and Direction of Air Movements at the Height of Sitting and Standing Positions

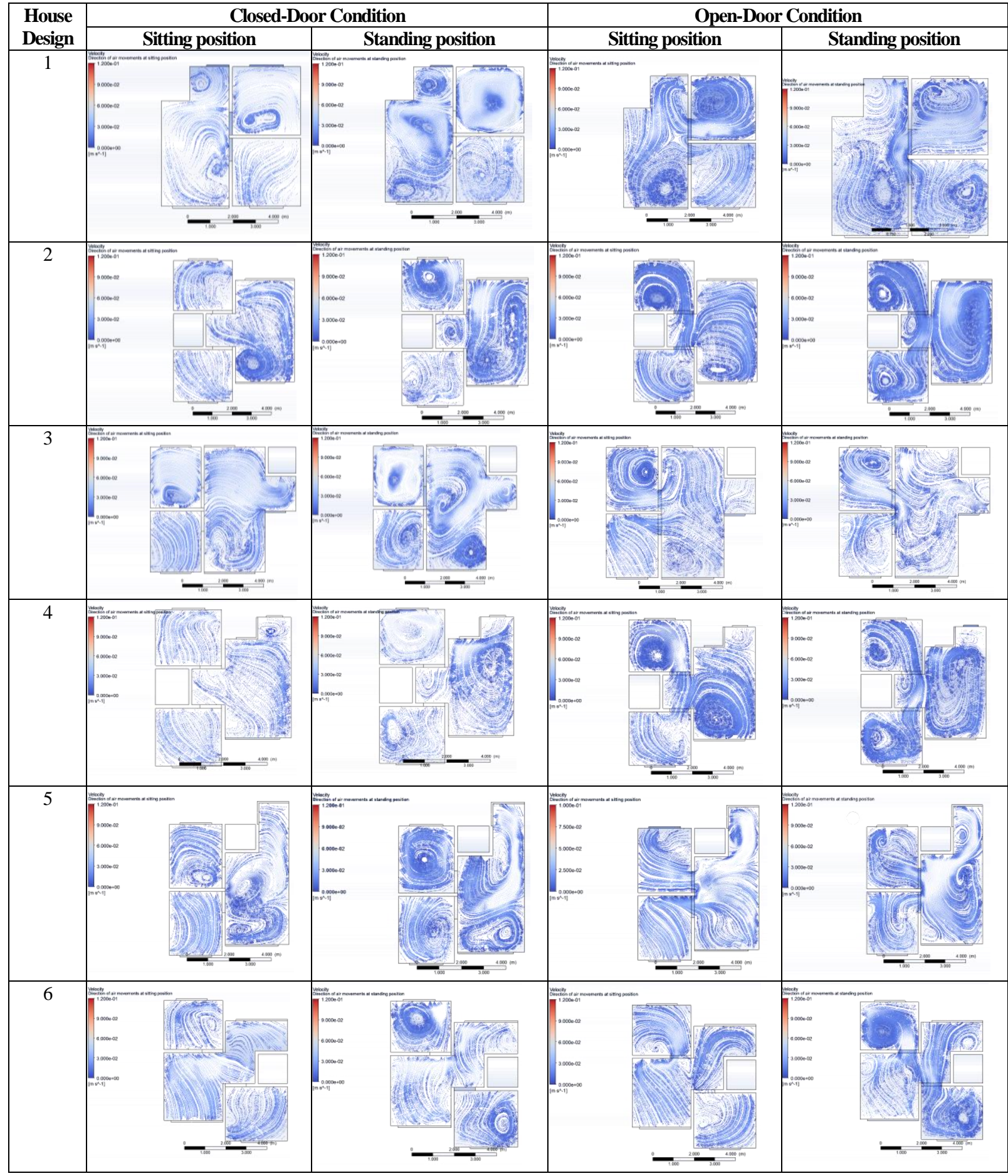

(Source: Author, 2020) 


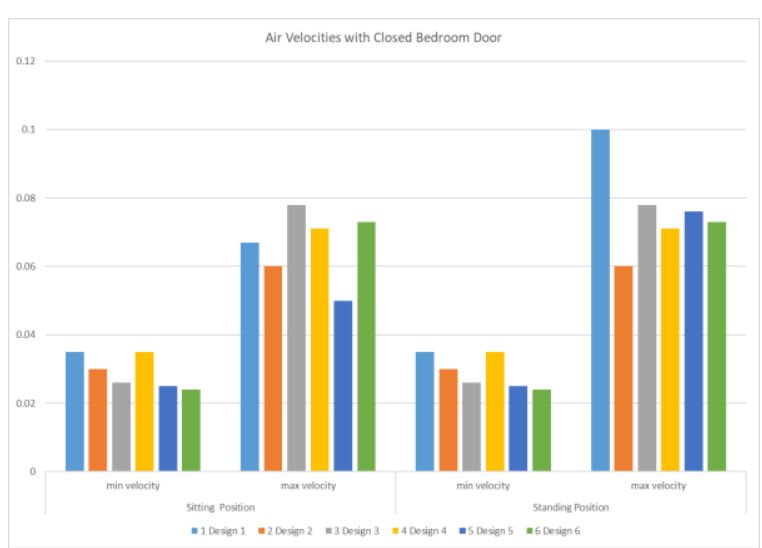

Fig. 1. Airflow Velocities with Closed Bedroom Door (Source: Author, 2020).

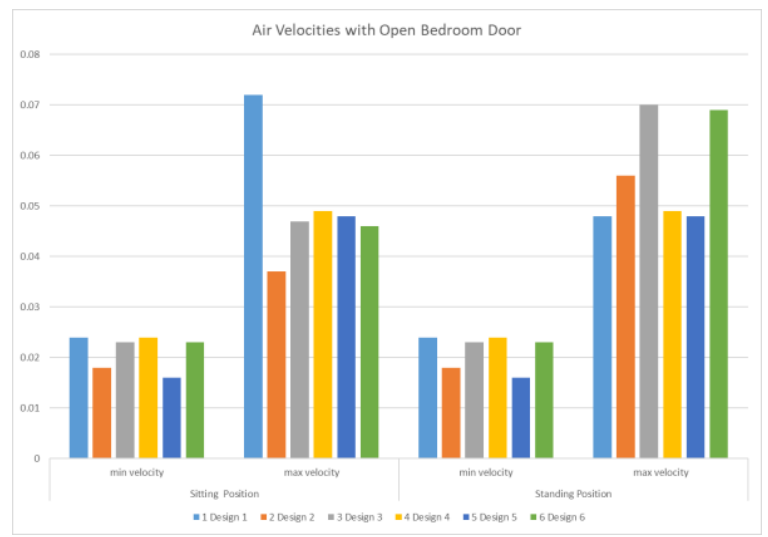

Fig. 2. Airflow Velocities with Open Bedroom Door (Source: Author, 2020).

Comparing the flow velocities, in the closeddoor condition, airflows at the standing height did not show a significant difference in values compared to the airflows at the sitting height, as indicated by Figure 1. Only designs No. 1 and No. 5 showed faster airflow velocities in the standing condition. All evaluated designs showed that there was a decrease in indoor airflow velocities compared to the velocity of air that entered the buildings. The lowest air velocities were generated by designs No. 2 and No. 5. Both designs generated airflows that had many turbulent vortices. Figure 2 shows the airflow velocities in the open-door condition. There were 3 designs that showed higher airflow velocities at the standing height compared to airflow velocities at the sitting height, namely design No. 2, 3, and 6. Designs No. 4 and 5 showed almost the same velocities at both heights, while design No. 1 showed a decrease in velocity.

The comparison between open-door and closeddoor conditions showed that the airflow velocities in the open-door condition tended to be lower than the ones in the closed-door condition, as can be seen in Figure 3. From the figure, it can also be seen that the designs that could maintain the indoor air velocities so that they could be close to the velocity of incoming air are floor plans No. 1, 3, and 6. In floor plan No. 2, flow velocities in both conditions and at both heights were rather similar, although they were lower compared to other layout shapes. Floor plan No. 4 had a rather high flow velocity in the closed-door condition, but in the open-door condition, the flow velocity was lower. Likewise, in floor plan No. 5, a rather high flow velocity only occurred at the standing height with a closed bedroom door.

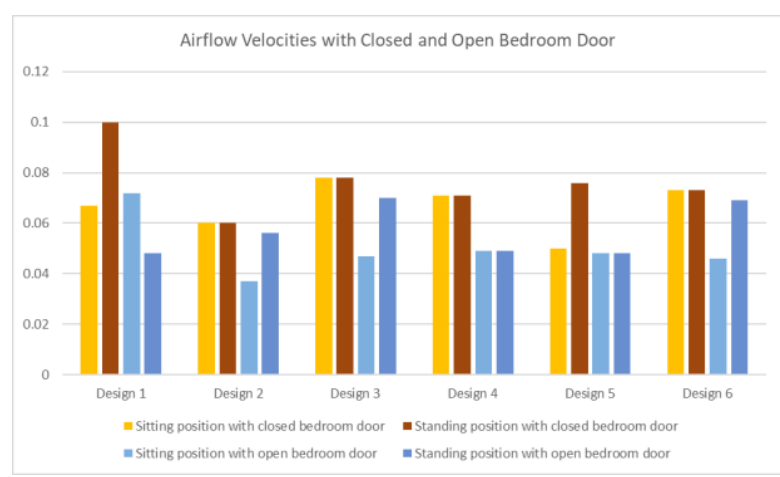

Fig. 3. Comparison of Airflow Velocities with Closed and Open Bedroom Door

\section{CONCLUSION}

The simulations that were conducted to see the airflows in six types 36 house designs provided an illustration of the effects of the placement of rooms and air vents on airflow patterns and airflow velocity. Airflow has an effect on the comfort and transmission of pollutants inside a room. Rooms that were arranged in a way that enabled a placement of ventilation that faced each other, even if they were in different rooms, made a rather great improvement on continuous airflow that did not form any turbulent vortices. Patterns of airflow that formed turbulent vortices are deemed to be unfavorable in relation to the effort to reduce occupants' exposure to pollutants, even though there are differing opinions regarding their effectiveness in forming thermal comfort. Air vents placed perpendicular to the entry path of air were less effective as exit paths, even though the sizes of the air vents were the same as the other designs. When comparing airflow velocities, the open-door condition actually generated lower velocities than the closeddoor condition. However, the open-door condition generated more continuous airflow patterns, which did not form any vortices. Layouts that generated a lot of vortices in their airflows, such as design No. 5, had lower air velocities. The results of this study are expected to be beneficial and can become the basis for consideration when designing natural ventilation in type 36 buildings. 


\section{ACKNOWLEDGMENT}

This research was supported by the Engineering Faculty, Tanjungpura University, Indonesia.

\section{REFERENCES}

Both, B., Szánthó, Z., \& Goda, R. (2016). Air velocity and turbulence distribution in a slot-ventilated room. CLIMA 2016 - Proceedings of the 12th REHVA World Congress, 5.

Chung, K. C., \& Hsu, S. P. (2001). Effect of ventilation pattern on room air and contaminant distribution. Building and Environment, 36(9), 989998. https://doi.org/10.1016/S0360-1323(00)000 51-2

Faulkner, W. B., Memarzadeh, F., Riskowski, G., Kalbasi, A., \& Ching-Zu Chang, A. (2015). Effects of air exchange rate, particle size and injection place on particle concentrations within a reduced-scale room. Building and Environment, 92, 246-255. https://doi.org/10.1016/j. buildenv.2015.04.034

Fulpagare, Y., \& Agrawal, N. (2013). Experimental investigation on room air flow pattern \& thermal comfort quantification. International Journal of Engineering Sciences \& Emerging Technologies, IJESET, 6(1), 120-132. http://www.ijeset. com/media/0002/15N11_IJESET0602120_v6_i ss1_120to132.pdf

Gong, N., Tham, K. W., Melikov, A. K., Wyon, D. P., Sekhar, S. C., \& Cheong, K. W. (2006). The acceptable air velocity range for local air movement in the tropics. HVAC and R Research, 12(4), 1065-1076. https://doi.org/10.1080/107 89669.2006.10391451.

Hawendi, S., \& Gao, S. (2016). Investigation of opening positions on the natural ventilation in a lowrise building by CFD analysis. International Conference on Fluid Flow, Heat and Mass Transfer, 151, 1-7. https://doi.org/10.11159/ ffhmt16.151.

Heiselberg, P., Bjørn, E., \& Nielsen, P. v. (2002). Impact of open windows on room airflow and thermal comfort. International Journal of Ventilation, 1(2), 91-100. https://doi.org/10.1080/147 33315.2002 .11683625$.

Heiselberg, P., Svidt, K., \& Nielsen, P. v. (2001). Characteristics of airflow from open windows. Building and Environment, 36(7), 859-869. https://doi.org/10.1016/S0360-1323(01)00012-9

Hu, S. C., Wu, Y. Y., \& Liu, C. J. (1996). Measurements of airflow characteristics in a full-scale clean room. Building and Environment, 31(2),
119-128. https://doi.org/10.1016/0360-1323(95) 00039-9

Liu, M., Heiselberg, P. K., Larsen, O. K., Mortensen, L., \& Rose, J. (2017). Investigation of different configurations of a ventilated window to optimize both energy efficiency and thermal comfort. Energy Procedia, 132, 478-483. https://doi. org/10.1016/j.egypro.2017.09.660

Liu, X., Lv, X., Peng, Z., \& Shi, C. (2020). Experimental study of airflow and pollutant dispersion in cross-ventilated multi-room buildings: Effects of source location and ventilation path. Sustainable Cities and Society, 52, 101822. https://doi. org/10.1016/j.scs.2019.101822

Liu, X., Wu, X., Chen, L., \& Zhou, R. (2018). Effects of internal partitions on flow field and air contaminant distribution under different ventilation modes. International Journal of Environmental Research and Public Health, 15(11). https://doi. org/10.3390/ijerph15112603

Marpaung, G. N. (2011). Analisis faktor-faktor yang mempengaruhi konsumen terhadap permintaan perumahan. JEJAK: Jurnal Ekonomi Dan Kebijakan, 4(2), 125-134. https://doi.org/10.15294/ jejak.v4i2.4647

Mediastika, C. E. (2002). Desan jendela bangunan domestik untuk mencapai "cooling ventilation" kasus uji: Rumah sederhana luas 45m2 di Yogyakarta. DIMENSI (Jurnal Teknik Arsitektur), 30(1). http://puslit2.petra.ac.id/ejournal/index. php/ars/article/view/15768.

Memarzadeh, F., \& Xu, W. (2012). Role of air changes per hour $(\mathrm{ACH})$ in possible transmission of airborne infections. Building Simulation, 5(1), 15-28. https://doi.org/10.1007/s12273-011-0053-4

Menteri Kesehatan Republik Indonesia. (2011). Peraturan menteri kesehatan Indonesia No. 1077/ Menkes/PER/2011 tentang pedoman penyehatan udara dalam ruang rumah.

Menteri Permukiman dan Prasarana Wilayah Republik Indonesia. (2002). Keputusan menteri permukiman dan prasarana wilayah nomor: 403/ KPTS/M/2002 tentang pedoman teknis pembangunan rumah sederhana sehat (RS sehat) (p. 6).

Perhimpunan Ergonomi Indonesia. (2013). Antropometri Indonesia.

http://antropometriindonesia.org/index.php/detail/sub/ 2/7/0/pengantar_antropometri.

Posner, J. D., Buchanan, C. R., \& Dunn-Rankin, D. (2003). Measurement and prediction of indoor air flow in a model room. Energy and Buildings, 35(5), 515-526. https://doi.org/10.1016/S03787788(02)00163-9. 
Prakash, D., \& Ravikumar, P. (2015). Analysis of thermal comfort and indoor air flow characteristics for a residential building room under generalized window opening position at the adjacent walls. International Journal of Sustainable Built Environment, 4(1), 42-57. https://doi.org/ 10.1016/j.ijsbe.2015.02.003

Sabaruddin, A., Hartini, \& Hermawan, Y. (2011). Modul Rumah Sehat. Kementerian Pekerjaan Umum, Badan Penelitian dan Pengambangan, Pusat Penelitian dan Pengembangan Permukiman.

Sacht, H., \& Lukiantchuki, M. A. (2017). Windows size and the performance of natural ventilation. Procedia Engineering, 196(June), 972-979. https://doi.org/10.1016/j.proeng.2017.08.038

Setyawan, H. A. (2020). Kebutuhan rumah baru. Kompas. https://kompas.id/baca/gaya-hidup/20 20/06/06/kebutuhan-rumah-baru/\#: : :text=Menurut data Kementerian PUPR\%2C angka, mencapai $7 \% 2 \mathrm{C6}$ juta unit.\&text=Terdiri dari 945.161 unit rumah,unit rumah untuk non MBR.

Simorangkir, E. (2018). Ini tipe rumah paling diminati orang RI. Detik Finance. https://finance.detik. com/properti/d-4209825/ini-tipe-rumah-palingdiminati-orang-ri

Suryanto HS, M. (2010). Analisis kepuasan konsumen rumah tipe 36 (Studi kasus perumahan Pondok Permata Suci Gresik). WAKTU Jurnal
Teknik UNIPA, 08(2), 43-53. http://jurnal.unipasby.ac.id/index.php/waktu/article/view/847.

Tanabe, S., \& Kimura, K. (1989). Importance of air movement for thermal comfort under hot and humid conditions. Proceedings of the Second ASHRAE Far East Conference on Air Conditioning in Hot Climates, Kuala Lumpur, Malaysia, January, 95-103.

Wargocki, P. (2013). The effects of ventilation in homes on health. International Journal of Ventilation, 12(2), 101-118. https://doi.org/10.1080/ 14733315.2013.11684005

Widiastuti, R., Hasan, M. I., Bramiana, C. N., \& Pramesti, P. U. (2020). CFD simulation on the natural ventilation and building thermal performance. IOP Conference Series: Earth and Environmental Science, 448(1). https://doi.org/10. 1088/1755-1315/448/1/012004

Xia, Y., Zhao, R., \& Niu, J. (2000). Effect of turbulent intensity on human thermal sensation in isothermal environment. Qinghua Daxue Xuebao/ Journal of Tsinghua University, 40(10), 100103.

Yang, T. Y., Riskowski, G. L., \& Chang, A. C. Z. (2019). Effects of air relative humidity and ventilation rate on particle concentrations within a reduced-scale room. Indoor and Built Environment, 28(3), 335-344. https://doi.org/10.1177/ $1420326 X 18773134$. 